\title{
Biosorption of Copper(II) and Iron(II) using Spent Mushroom Compost as Biosorbent
}

\author{
Ain Nihla Kamarudzaman ${ }^{1,2 *}{ }^{\mathbb{D}}$, Siti Nur Ain Che Adan ${ }^{1}$, Zulkarnain Hassan ${ }^{1,2} \mathbb{D}$, \\ Mahyun Ab Wahab 1,2过, Salwa Mohd Zaini Makhtar 1,2 ${ }^{\mathbb{D}}$, Nor Amirah Abu Seman 1,2 ${ }^{\mathbb{D}}$, Mohd Faizal \\ Ab Jalil ${ }^{3}$, Dwi Handayani ${ }^{4}[$, Achmad Syafiuddin 4 (1) \\ 1 Faculty of Civil Engineering Technology, Universiti Malaysia Perlis, Kompleks Pusat Pengajian Jejawi 3, 02600 Arau, \\ Perlis, Malaysia \\ 2 Centre of Excellence, Water Research and Environmental Sustainability Growth (WAREG), Universiti Malaysia Perlis, \\ 02600 Arau, Perlis, Malaysia \\ 3 Kedah State Department of Environment, Aras 2 Menara Zakat, Jalan Telok Wanjah, 05450 Alor Setar, Kedah, Malaysia; \\ 4 Department of Public Health, Universitas Nahdlatul Ulama Surabaya, Surabaya 60237, Indonesia \\ * Correspondence: ainnihla@unimap.edu.my (A.N.K.)
}

Scopus Author ID 55898991400

Received: 20.09.2021; Revised: 2.11.2021; Accepted: 5.11.2021; Published: 1.12.2021

\begin{abstract}
The application of the biosorption process and agricultural waste to treat heavy metals has drawn much attention. This method seems to be a more economical, environmentally friendly, and simple way for removing heavy metals from effluents. The study was conducted to explore the efficiency of the biosorption process utilizing spent mushroom compost to remove copper (II) and iron (II) from synthetic wastewater. Biosorption studies at different operating parameters, such as biosorbent dosage (1.0 - 5.0 g), $\mathrm{pH}$ ( $\mathrm{pH} 4-8)$, contact time (1 - 30 minutes), and initial heavy metal concentration $(10-100 \mathrm{mg} / \mathrm{L})$, were conducted in batch experiments. The highest performance for copper (II) and iron (II) biosorption was found at $5.0 \mathrm{~g}$ biosorbent dosage of spent mushroom compost, unadjusted $\mathrm{pH}$ 6, 10 minutes of contact time, and $10 \mathrm{mg} / \mathrm{L}$ of initial concentration. The study was well fitted to the Langmuir isotherm model $\left(\mathrm{R}^{2}>0.95\right)$ for copper (II) and iron (II) biosorption, which are much greater compared to the Freundlich model. The study is also very well suited to the pseudo-second-order $\left(\mathrm{R}^{2}>\right.$ 0.999) than the pseudo-first-order kinetic models. In conclusion, the spent mushroom compost has the potential to be an effective biosorbent for removing copper (II) and iron (II) from synthetic wastewater.
\end{abstract}

Keywords: biosorption; copper; iron; spent mushroom compost; wastewater.

(C) 2021 by the authors. This article is an open-access article distributed under the terms and conditions of the Creative Commons Attribution (CC BY) license (https://creativecommons.org/licenses/by/4.0/).

\section{Introduction}

Heavy metals are persistent contaminants in the ecosystem because they cannot be eliminated. Most heavy metals are known to be toxic and carcinogenic. Heavy metals can be released by natural processes as well as anthropogenic activities into the environment. Heavy metals are natural elements in the earth's crust and are mostly found in soils, rocks, sediments, and waters with natural background concentrations [1]. Acidification, erosion, and weathering phenomena are natural processes that bring heavy metals into the environment [2-4]. For example, heavy rainfall or surface water runoff can leach heavy metals from geological formations. Meanwhile, anthropogenic activities such as agricultural activities, domestic waste, industrial processes, landfills, sewage discharge, mining, and emissions from vehicles also contribute to the existence of heavy metals in the environment [5-8]. The presence of anthropogenic heavy metals far outweighs in terms of quantity and concentrations compared 
to the natural processes [1]. Amongst the above-listed anthropogenic activities, the industrial processes constitute the major contributor to heavy metals pollution due to inefficient treatment and poor management.

In many countries, laws about water pollution control have been introduced. The efficient method of treating heavy metals from industrial effluent discharge has now become a crucial concern. There are various methods of industrial wastewater treatment which are based on various criteria. Chemical precipitation, membrane filtration, electrochemical, reduction, oxidation, flotation, and ion exchange are examples of heavy metals treatment methods [9]. Unfortunately, the existing heavy metals treatment methods have several limitations, including high operation and maintenance costs, complicated processes, high chemical consumption, and treatment that produces a high quantity of toxic sludge [10-12]. In addition, some of these conventional treatment operations are not economic and ineffective, particularly at low heavy metal concentrations of less than $100 \mathrm{mg} / \mathrm{L}[13,14]$. As a solution, other treatments such as biosorption have been used and focused on due to certain aspects such as simple operation, economical, efficiency, and environmentally friendly.

Biosorption is the alternative process for treating heavy metals. It is an independent method of the physio-chemical passive metabolite by deploying biosorbent from non-living biological materials. Biosorption is a suggested heavy metal treatment process because it is an environmentally friendly, economical, efficient, and simple technique [15]. Furthermore, this process is considered low-cost in operation and relatively more effective in treating heavy metals from dilute solutions or low concentrations of heavy metals [16]. According to [13], because of its ability to efficiently sequester dissolved heavy metals from dilute solutions, the biosorption process is an appropriate treatment for industrial wastewater comprising large amounts and low concentrations of heavy metals. The biosorption process can easily renew biosorbents for many reuses, producing no hazardous sludge [15]. In addition, recovering heavy metals from biosorbents can be carried out by applying several physical and chemical processes without damaging the structure of biosorbents [17].

However, the key issue of the biosorption process is identifying the most feasible biosorbent from a vast array of easily available and low-cost biosorbents. A wide range of naturally available materials can be selected as biosorbent to bind and eliminate pollutants from industrial wastewater. Biosorbents can be made from any type of biomass, including plants, animals, and microorganisms, and waste from agriculture, factories, and by-products from various industries. An ideal biosorbent must have several characteristics, including easy availability in large quantities, low economic value, a high heavy metal affinity, and the biosorbent can be reused many times $[5,12,18]$. Spent mushroom compost is a type of residual material produced by mushroom production farms after the harvesting period of mushrooms. It is a mixture of mushroom mycelium, rubber tree sawdust, rice husk, and calcium carbonate. Mushroom farms dump approximately 24 tonnes of spent mushroom compost every month on average [19]. For mushroom farmers, disposing of unused mushroom compost is a major issue. Thus, spending mushroom compost as a biosorbent appears to be a sustainable solution to treating heavy metals from industrial waste and simultaneously solving the waste issue in mushroom farms.

The study intends to explore the effectiveness of agricultural by-products, namely spent mushroom compost, in treating copper (II) and iron (II). The explicit aims of the present study are as follows: 1) to examine and optimize the biosorption efficiency at varying factors such as biosorbent dosage, $\mathrm{pH}$, contact time, and initial heavy metal concentration, 2) to evaluate the 
isotherm and kinetic studies for biosorption of copper (II) and iron (II) using spent mushroom compost.

\section{Materials and Methods}

\subsection{Biosorbent material preparation.}

About $3 \mathrm{~kg}$ of spent mushroom compost material was supplied by Amirul Mushrooms Farming Sdn. Bhd. in Kangar, Perlis. The biosorbent material was autoclaved at a temperature of $121^{\circ} \mathrm{C}$, under the pressure of 18 psi for 15 minutes. Then, the biosorbent material was placed in an oven at a temperature of $60^{\circ} \mathrm{C}$ for 48 hours to reduce the moisture content [20]. The material was then crushed and sieved using a sieve tray to get a particle size less than $1.18 \mathrm{~mm}$. Next, the biosorbent material was washed using distilled water to eliminate undesirable elements. Lastly, after drying in a $60^{\circ} \mathrm{C}$ oven, the biosorbent material was stored in the drying cabinet [20].

\subsection{Preparation of stock solution.}

Analytical grade copper (II) sulfate pentahydrate $\left(\mathrm{CuSO}_{4} .5 \mathrm{H}_{2} \mathrm{O}\right)$ and iron (II) sulfate heptahydrate $\left(\mathrm{FeSO}_{4} .7 \mathrm{H}_{2} \mathrm{O}\right)$ were used and prepared for heavy metals stock solution.

\subsection{Biosorption experimental procedures.}

The studies were carried out under batch experiments and were performed by filling conical flasks with a known quantity of biosorbent material, followed by the addition of $50 \mathrm{~mL}$ of heavy metal solution. The conical flasks were then placed on the orbital shaker for a predetermined contact period and operated at a speed of $125 \mathrm{rpm}$. After completion of the treatment, the biosorbent was filtered using a filter paper size of $125 \mathrm{~mm}$ [21]. Then, the filtrate was analyzed using an Atomic Absorption Spectrometer (AAS). The optimum biosorption conditions were determined at varying parameters, such as biosorbent dosage, $\mathrm{pH}$, contact time, and initial heavy metal concentration. Table 1 summarises the operating conditions for copper (II) and iron (II) biosorption employed in this study. The batch biosorption experiments for each heavy metal were conducted separately.

Table 1. Summary of operating conditions for copper (II) and iron (II) biosorption.

\begin{tabular}{l|c|c|c|c}
\multirow{2}{*}{\multicolumn{1}{c}{ Parameter }} & \multicolumn{4}{c}{ Operational conditions } \\
\cline { 2 - 5 } & Biosorbent dosage $(\mathbf{g})$ & $\mathbf{p H}$ & Contact time (min) & Initial Concentration (mg/L) \\
\hline Biosorbent dosage & $1-5$ & 5 & 10 & 50 \\
\hline $\mathrm{pH}$ & 5 & $4-8$ & 10 & 50 \\
\hline Contact time & 5 & 6 & $1-30$ & 50 \\
\hline Initial concentration & 5 & 6 & 10 & $10-100$
\end{tabular}

\section{Results and Discussion}

The effects of parameters such as biosorbent dosage, $\mathrm{pH}$, contact time, and initial heavy metal concentration on the removal of copper (II) and iron (II) were investigated.

\subsection{Biosorbent dosage.}

Figure 1 presents the effects of increasing biosorbent dosage on copper (II) and iron (II) biosorption. The graph indicated that copper (II) and iron (II) biosorption gradually increased from $19.47 \%$ to $59.62 \%$ and $20.58 \%$ to $58.30 \%$, respectively. The percentage removal was 
increased as the amount of biosorbent was raised from 1.0 to $5.0 \mathrm{~g}$. The optimum biosorbent dosage for copper (II) and iron (II) biosorption was observed at $5.0 \mathrm{~g}$ each. The maximum uptake capacities of copper (II) and iron (II) were observed at $0.31 \mathrm{mg} / \mathrm{g}$ and $0.36 \mathrm{mg} / \mathrm{g}$, respectively. When the amount of biosorbent dosage was increased, so did the copper (II) and iron (II) biosorption, which might be attributed to an increase in the availability of binding sites on the biosorbent's surface [22-23]. According to [24], increasing the amount of biosorbent dosage will increase the availability of pores, surface area, active binding sites, and unsaturated sites, which all could contribute to increased biosorption effectiveness. Besides, studies on agricultural waste biosorbents such as abandoned mushroom compost [25], Cucumis melo rind [26], pomegranate peel [27], Tilapia Mossambica fish scale [28], and fruit peels [29] were found to have similar phenomena to this study's.

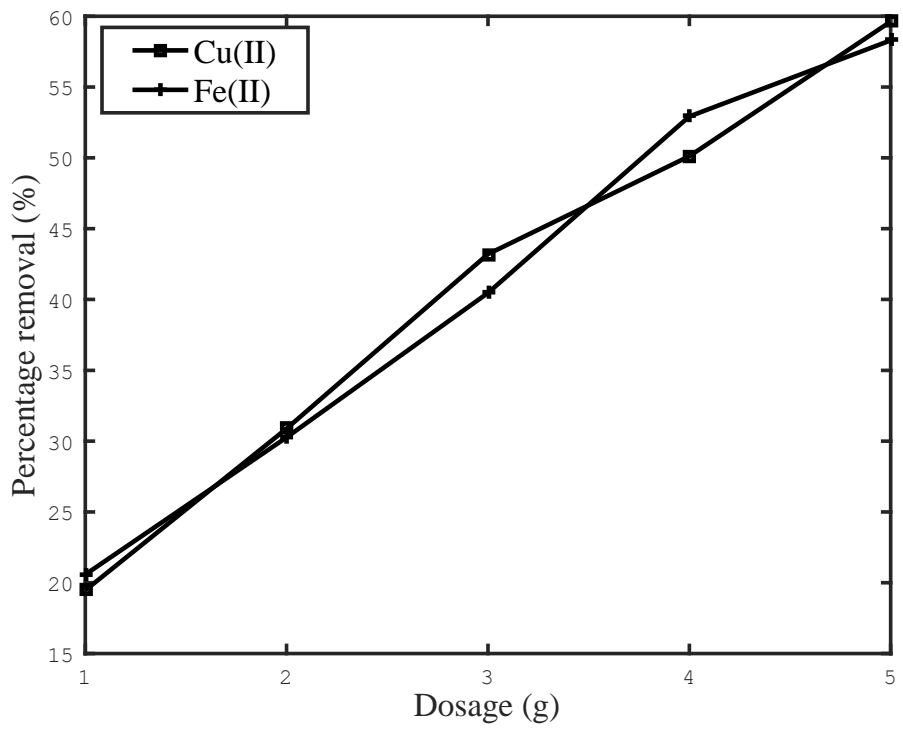

Figure 1. Copper(II) and iron(II) biosorption versus biosorbent dosage.

\section{2. $p H$.}

The highly crucial factor regulating heavy metal biosorption is $\mathrm{pH}$. Contrasts in $\mathrm{pH}$ straightforwardly influence the serious capacity of hydrogen ions with heavy metal ions at the dynamic binding sites on the biosorbent surface [30]. The influence of $\mathrm{pH}$ on copper (II) and iron (II) biosorption was studied in the $\mathrm{pH}$ range of 4 to 8 . Figure 2 presents the copper (II) and iron (II) biosorption results with varying $\mathrm{pH}$ values. The performance of copper (II) and iron (II) biosorption improved as the $\mathrm{pH}$ value raised from $\mathrm{pH} 4$ to 5. The highest biosorption efficiencies for both heavy metals were found at $\mathrm{pH} 6,42.21 \%$, and $62.19 \%$ for copper (II) and iron (II), respectively. Then, the highest uptake capacity for copper (II) was observed at 0.70 $\mathrm{mg} / \mathrm{g}$, while for iron (II), it was at $0.62 \mathrm{mg} / \mathrm{g}$. At pH 7 to 8 , the uptake capacity for both heavy metals decreased. The low uptake capacity at low $\mathrm{pH}$ could be because the biosorbent surface is protonated and acts as a positive charge [21]. Therefore, the charge repulsion formed and decreased biosorption uptake of copper (II) and iron (II) [27,31]. Meanwhile, when pH is raised, the binding sites on the biosorbent's surface deprotonate, and the charge attraction is reinforced [11,21]. Consequently, copper (II) and iron (II) biosorption uptake increased significantly. Similar trends were observed by employed coconut waste [31], pine fruit [32], banana trunks [33], white lupine husk [34], living biofilms [35], and eggshells [36] to treat copper (II) and/or iron (II). 


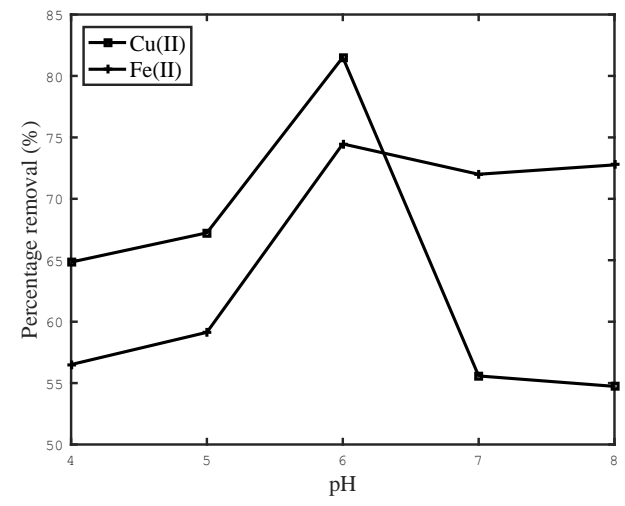

Figure 2. Copper (II) and iron (II) biosorption versus $\mathrm{pH}$.

\subsection{Contact time.}

The efficiency of copper (II) and iron (II) biosorption using spent mushroom compost at varying contact times are presented in Figure 3. Copper (II) and iron (II) biosorption were initially rapid, and then equilibrium was reached, as shown in Figure 3. Heavy metals removal increased as contact time increased. The equilibrium phase for copper (II) and iron (II) biosorption were $55.51 \%$ and $43.38 \%$, respectively, achieved after 10 minutes of contact time. The uptake capacity for copper (II) and iron (II) biosorption was $0.28 \mathrm{mg} / \mathrm{g}$ and $0.26 \mathrm{mg} / \mathrm{g}$, respectively. This proved that heavy metal ions easily occupy the active binding sites on the biosorbent's surface. Furthermore, during the initial phase, this led to a significant rise in heavy metal biosorption [37]. The performance of heavy metals biosorption was improved rapidly in the initial phase due to the availability of greater surface area on the biosorbent for heavy metal biosorption [38-40]. Similar trends of contact time using Agaricus bisporus mushroom [41], rice husk ash [30], chemically modified rise husk [42], and green algae [43] indicate that heavy metal sorption was very efficient in the first few minutes of the process. Then the percentage of heavy metals biosorption reaches the equilibrium phase.

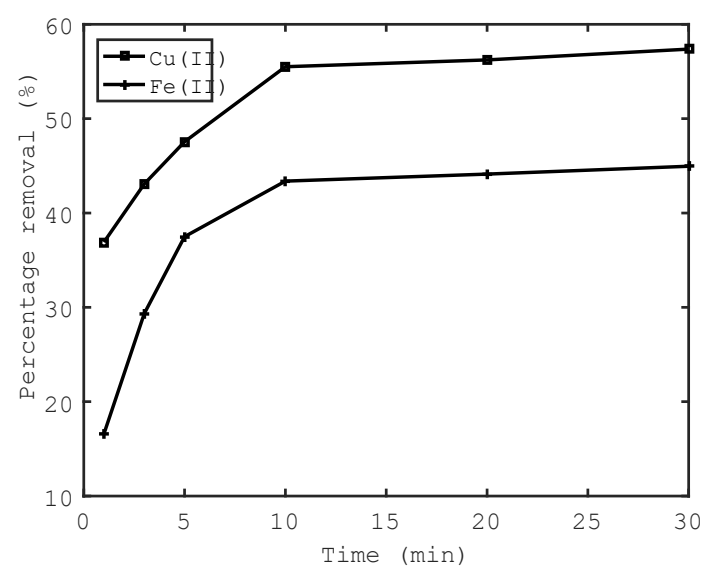

Figure 3. Copper (II) and iron (II) biosorption versus contact time.

\subsection{Initial heavy metals concentration.}

Figure 4 depicts the influence of different concentrations on copper (II) and iron (II) biosorption. The copper (II) and iron (II) biosorption gradually decreased from $55.22 \%$ to $23.48 \%$ and $61.71 \%$ to $29.10 \%$, respectively, when the initial concentration of both heavy metals was increased between 10 to $100 \mathrm{mg} / \mathrm{L}$. The highest uptake capacities of copper (II) and iron (II) were obtained at $0.26 \mathrm{mg} / \mathrm{g}$ and $0.33 \mathrm{mg} / \mathrm{g}$, respectively. The decrease in biosorption 
efficiency was probably due to the saturation of the binding sites on the surface of the biosorbent with more heavy metal ions in the solution [10]. After all, the percentage removal of heavy metals was observed with higher biosorption levels at lower heavy metal concentrations [41]. This occurs because at a lower initial heavy metals concentration, the ratio of the initial moles of heavy metals to the available binding sites is low, and thus, adequate binding sites are available to accommodate all the heavy metals ions $[44,45]$.

On the other hand, the biosorption uptake capacity enhanced with increasing initial heavy metals concentration due to the high concentration gradient between the heavy metals on the biosorbent and the heavy metals in the solution. A large concentration gradient is a driving force in overcoming the resistance of pollutant mass transfer between the aqueous and solid phases. This result will lead to an increase in heavy metals uptake [46]. Similar findings have been observed in other studies, such as pomegranate peel [27], Pleurotus spent mushroom compost [47], pine cone powder [48], and pumpkin stem [49] as biosorbents. The results indicated that these biosorbents have great potential as an optional treatment for removing heavy metals from effluents.

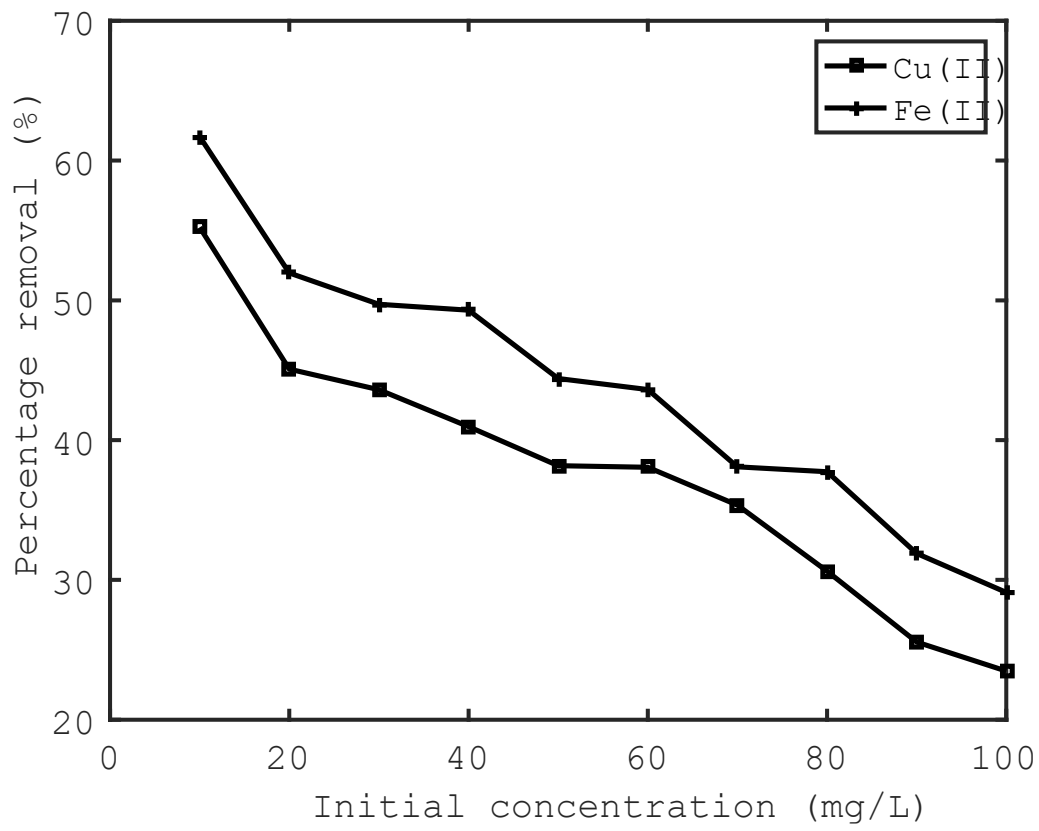

Figure 4. Copper (II) and iron (II) biosorption versus initial concentration.

\subsection{Evaluation of existing mathematical models.}

The copper (II) and iron (II) biosorption experimental data were also assessed using isotherm models (Langmuir and Freundlich isotherms) and kinetic models (pseudo-first-order and pseudo-second-order kinetics).

\subsubsection{Isotherm models.}

Regression analysis using the linearized equation of Langmuir and the Freundlich isotherm models for copper (II) and iron (II) was established in Figure 5 and Figure 6, respectively. The linearisation of the Langmuir model helps estimate constant parameters such as maximum sorption capacity, $\mathrm{q}_{\mathrm{e}}$, and the Langmuir constant, $\mathrm{b}$, whereas the Freundlich model provides information about $\mathrm{n}$ and $\mathrm{K}_{\mathrm{f}}$ values, which represent binding energy and bond strength, respectively [50]. Table 2 summarises the constant parameters of the Langmuir and Freundlich models. The findings indicated the experimental data were well fitted to the Langmuir 
biosorption isotherms model for copper (II) and iron (II) biosorption since the coefficient of determination, $\mathrm{R}^{2}$ values were higher than the Freundlich model. These results suggest that the copper (II) and iron (II) biosorption on the surface of spent mushroom compost occurred in monolayer biosorption [51,52]. It has been widely known that the Langmuir biosorption isotherm assumes that biosorption occurs at specific sites within the surface of biosorbent [53]. Therefore, there is no further binding process at active sites once they are occupied. The finding is consistent with other biosorbents such as red mud [54] for copper (II) removal and durian leaves for iron (II) removal [55], which also fitted the Langmuir model.

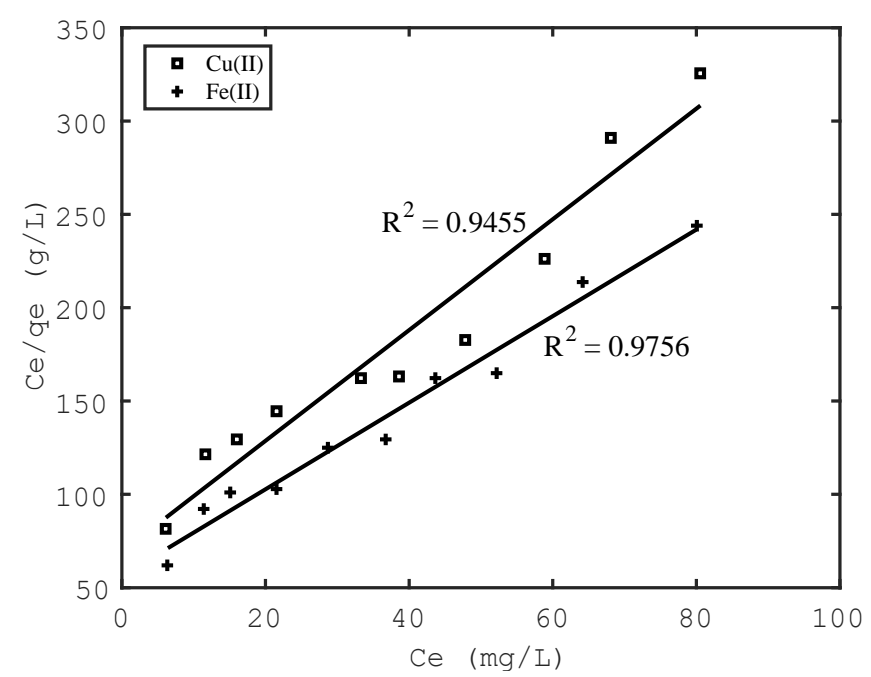

Figure 5. Evaluation of copper (II) and iron (II) biosorption using the Langmuir model.

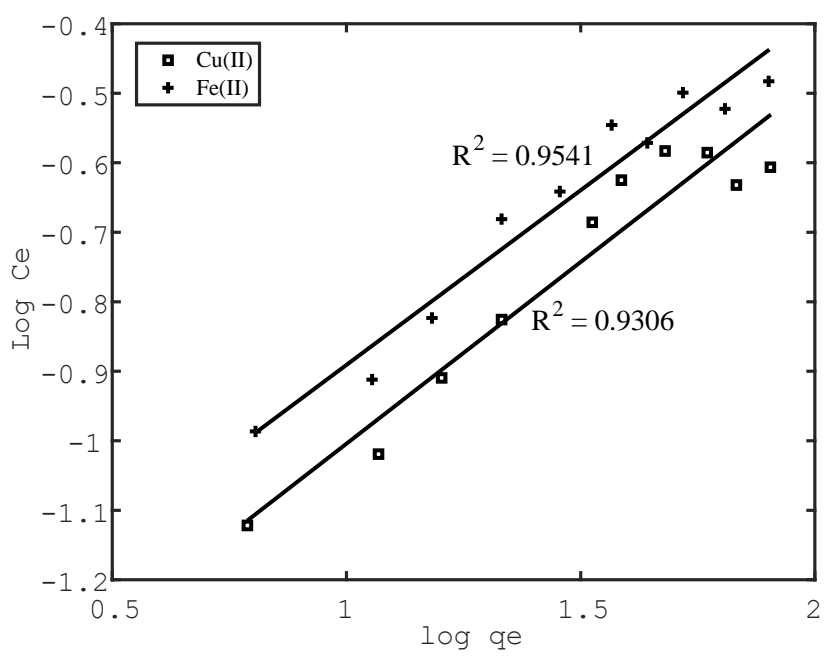

Figure 6. Evaluation of copper (II) and iron (II) biosorption using the Freundlich model.

Table 2. Isotherm constant parameters for copper (II) and iron (II) biosorption.

\begin{tabular}{c|c|c|c|c|c|c}
\multirow{2}{*}{ Heavy metal } & \multicolumn{3}{|c|}{ Langmuir parameters } & \multicolumn{3}{c}{ Freundlich parameters } \\
\cline { 2 - 7 } & $\mathbf{q}(\mathbf{m g} / \mathbf{g})$ & $\mathbf{b}(\mathbf{L} / \mathbf{m g})$ & $\mathbf{R}^{\mathbf{2}}$ & $\mathbf{K}_{\mathbf{F}}$ & $\mathbf{n}$ & $\mathbf{R}^{\mathbf{2}}$ \\
\hline Copper (II) & 0.34 & 0.04 & 0.9452 & 0.22 & 1.91 & 0.9306 \\
\hline Iron (II) & 0.43 & 0.04 & 0.9756 & 0.25 & 1.99 & 0.9541
\end{tabular}

\subsubsection{Kinetic models.}

Regression analysis of the linearized equations of pseudo-first-order and pseudosecond-order kinetic models for copper (II) and iron (II) biosorption are shown in Figure 7 and Figure 8, respectively. Table 3 summarizes the calculated constant parameters of the pseudofirst-order and pseudo-second-order kinetic models. The findings indicated that the copper (II) and iron (II) biosorption excellent fitted the pseudo-second-order as high coefficient of 
determination values were achieved compared to the pseudo-first-order kinetic model. This model suggests that the limiting factor for the biosorption process is chemisorption, which involves valence force through the sharing of electrons $[11,56]$. This assumes that multiple simultaneous mechanisms exist during copper (II) and iron (II) biosorption [21]. The finding is consistent with other studies, such as [30,57,58] and [59]. Experimental data were also better fitted to the pseudo-second-order kinetic model than the first-order kinetic model.

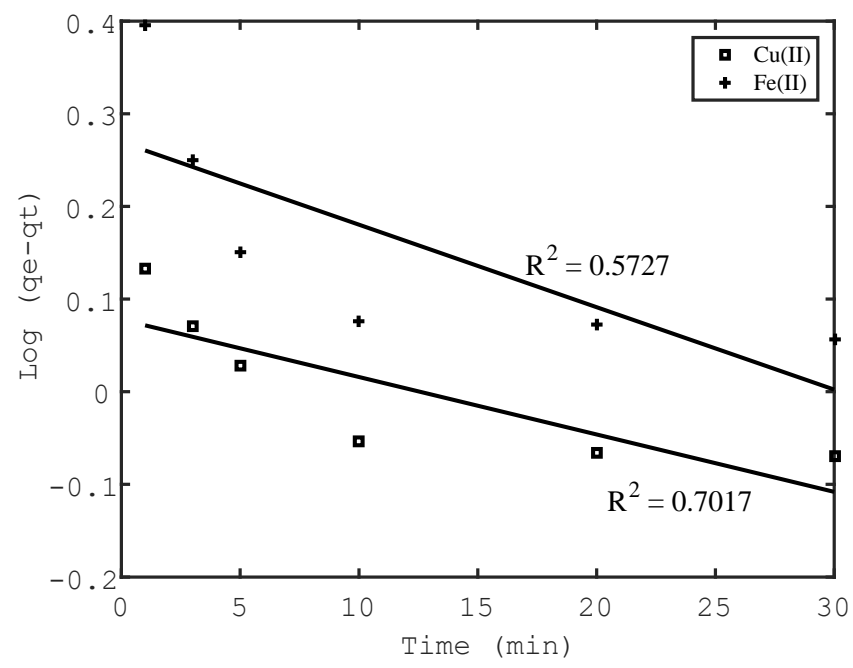

Figure 7. Evaluation of copper (II) and iron (II) biosorption using the pseudo-first-order kinetic model.

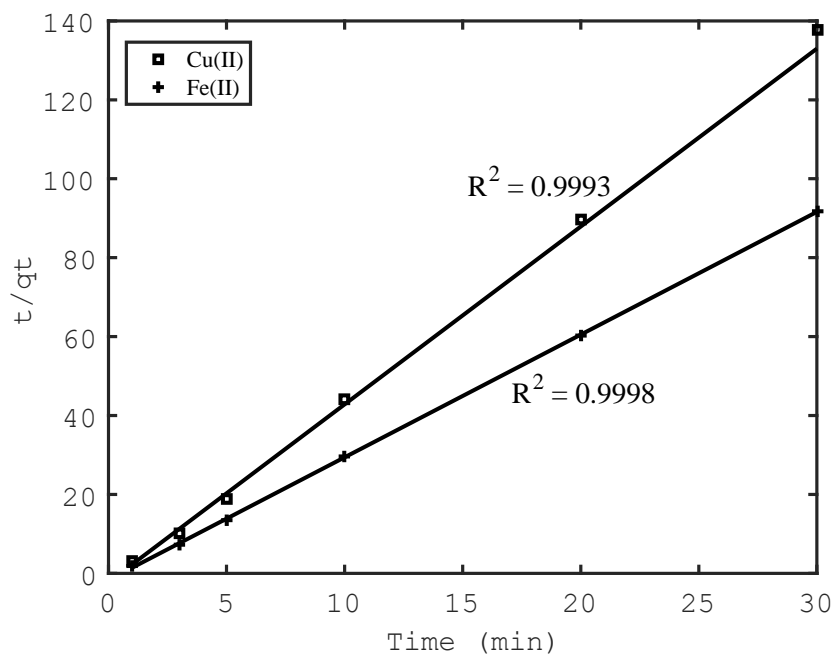

Figure 8. Evaluation of copper (II) and iron (II) biosorption using the pseudo-second-order kinetic model.

Table 3. Pseudo-first order and pseudo-second-order parameters for copper (II) and iron (II) biosorption.

\begin{tabular}{c|c|c|c|c|c|c}
\multirow{2}{*}{ Heavy metal } & \multicolumn{3}{|c|}{ Pseudo-First Order } & \multicolumn{3}{c}{ Pseudo-Second Order } \\
\cline { 2 - 7 } & $\mathbf{q}_{\mathbf{e}}(\mathbf{m g} / \mathbf{g})$ & $\mathbf{K}_{\mathbf{1}}$ & $\mathbf{R}^{\mathbf{2}}$ & $\mathbf{q} \mathbf{e}(\mathbf{m g} / \mathbf{g})$ & $\mathbf{K}_{\mathbf{2}}$ & $\mathbf{R}^{\mathbf{2}}$ \\
\hline Copper (II) & 1.08 & 0.01 & 0.7017 & 0.22 & 9.00 & 0.9993 \\
\hline Iron (II) & 1.31 & 0.02 & 0.5727 & 0.32 & 5.66 & 0.9998
\end{tabular}

\section{Conclusions}

Copper (II) and iron (II) biosorption using spent mushroom compost was investigated in batch experiments with varying operating conditions. The experimental investigations indicated the copper (II) and iron (II) biosorption are highly influenced by the amount of biosorbent, $\mathrm{pH}$, contact time, and initial heavy metal concentration. The best operating parameters to achieve higher efficiency for copper (II) and iron (II) biosorption were obtained using $5.0 \mathrm{~g}$ of biosorbent amount, $\mathrm{pH}$ of 6,10 minutes of contact time, and $10 \mathrm{mg} / \mathrm{L}$ of initial concentration. The biosorption isotherm and kinetic of spent mushroom compost biosorbent 
were also determined throughout this study. The coefficient of determination $\left(R^{2}>0.95\right)$ for copper (II) and iron (II) biosorption indicated that the results adapted fit to the Langmuir isotherm. This implies that the biosorption mechanism for copper (II) and iron (II) ions into spent mushroom compost is accompanied by a monolayer pattern. Next, the copper (II) and iron (II) biosorption were remarkably fitted $\left(\mathrm{R}^{2}>0.999\right)$ to a pseudo-second-order kinetic model. The spent mushroom compost biosorbent is appropriate for use in the biosorption process. Therefore, spent mushroom compost biosorbent has a high chance of reducing solid waste management problems related to mushroom cultivation farms. In the future, the impact of other variables such as temperature, size of particles, and the existence of other elements or organics pollutants may also be studied to enhance the study of biosorption.

\section{Funding}

This research received no external funding.

\section{Acknowledgments}

We are grateful for the university resources provided by Universiti Malaysia Perlis (UniMAP), Malaysia. We also thank the Faculty of Civil Engineering Technology, UniMAP, for providing us with laboratory facilities.

\section{Conflicts of Interest}

The authors declare no conflict of interest.

\section{References}

1. Mohammed, A.S.; Kapri, A.; Goel, R. Heavy metal pollution: source, impact, and remedies. In: Biomanagement of Metal-Contaminated Soils, Environmental Pollution. Khan, M.; Zaidi, A.; Goel, R.; Musarrat, J. Eds.; Springer: Dordrecht, Volume 20, 2011; pp. 1-28, https://doi.org/10.1007/978-94-0071914-9_1.

2. Paul, D. Research on heavy metal pollution of river Ganga: A review. Annals of Agrarian Science 2017, 15, 278-286, https://doi.org/10.1016/j.aasci.2017.04.001.

3. Jaishankar, M.; Tseten, T.; Anbalagan, N.; Mathew, B.B.; Beeregowda, K.N. Toxicity, mechanism and health effects of some heavy metals. Interdisciplinary Toxicology 2014, 7, 60-72, https://doi.org/10.2478/intox2014-0009.

4. Tajam, J.; Kamal, M.L. Marine environmental risk assessment of Sungai Kilim, Langkawi, Malaysia: Heavy metal enrichment factors in sediments as assessment indexes. International Journal of Oceanography 2013, 1-6, https://doi.org/10.1155/2013/482451.

5. Elgarahy, A.M.; Elwakeel, K.Z.; Mohammad, S.H.; Elshoubaky, G.A. A critical review of biosorption of dyes, heavy metals and metalloids from wastewater as an efficient and green process. Cleaner Engineering and Technology 2021, 4, https://doi.org/10.1016/j.clet.2021.100209.

6. Abdullah, M.Z.; Louis, V.C.; Abas, M.T. Metal pollution and ecological risk assessment of Balok River sediment, Pahang, Malaysia. American Journal of Environmental Engineering 2015, 5, 1-7.

7. Gautam, R.K.; Sharma, S.K.; Mahiya, S.; Chattopadhyaya, M.C. Contamination of heavy metals in aquatic media: transport, toxicity and technologies for remediation. In: Heavy Metals In Water: Presence, Removal and Safety. Sharma, S.K. Eds.; The Royal Society of Chemistry: Bangalore, India, 2014; pp. 1-24, https://doi.org/10.1039/9781782620174-00001.

8. Mudhoo, A.; Garg, V.K.; Wang, S. Heavy metals: toxicity and removal by biosorption. In: Environmental Chemistry for a Sustainable World. Environmental Chemistry for a Sustainable World. Lichtfouse, E.; Schwarzbauer, J.; Robert, D. Eds.; Springer: Dordrecht, Volume 2, 2012; pp. 379-442, https://doi.org/10.1007/978-94-007-2439-6_10.

9. Alalwan, H.A.; Kadhom, M.A.; Alminshid, A.H. Removal of heavy metals from wastewater using agricultural by-products. Journal of Water Supply: Research and Technology-Aqua 2020, 69, 99-112, https://doi.org/10.2166/aqua.2020.133.

10. Rizzuti, A.M.; Winston, R.J.; Orr, I.S. Biosorption of copper from aqueous solutions utilizing agricultural wastes. Remediation 2021, 31, 39-46, https://doi.org/10.1002/rem.21674. 
11. Tay, C.C.; Liew, H.H.; Redzwan, G.; Yong, S.K.; Surif, S.; Abdul-Talib, S. Pleurotus ostreatus spent mushroom compost as green biosorbent for nickel (II) biosorption. Water Science \& Technology 2011, 64, 2425-2432, https://doi.org/10.2166/wst.2011.805.

12. Volesky, B. Biosorption and me. Water Research 2007, 41, 4017-4029, https://doi.org/10.1016/j.watres.2007.05.062.

13. Wang, J.; Chen, C. Biosorbents for heavy metals removal and their future. Biotechnology Advances 2009, 27 , 195-226, https://doi.org/10.1016/j.biotechadv.2008.11.002.

14. Calero, M.; Hernáinz, F.; Blázquez, G.; Tenorio, G. Study of Cr(III) biosorption in a fixed-bed column. Journal of Hazardous Materials 2009, 171, 886-893, https://doi.org/10.1016/j.jhazmat.2009.06.082.

15. Javanbakht, V.; Alavi, S.A.; Zilouei, H. Mechanisms of heavy metal removal using microorganisms as biosorbent. Water Science and Technology 2014, 69, 1775-1787, https://doi.org/10.2166/wst.2013.718.

16. Verma, V.K.; Tewari, S.; Rai, J.P.N. Ion exchange during heavy metal biosorption from aqueous solution by dried biomass of Macrophytes. Bioresource Technology 2008, 99, 1932-1938, https://doi.org/10.1016/j.biortech.2007.03.042.

17. Park, D.; Yun, Y.S.; Park, J.M. The past, present, and future trends of biosorption. Biotechnology and Bioprocess Engineering 2010, 15, 86-102, https://doi.org/10.1007/s12257-009-0199-4.

18. Kurniawan, A.; Sisnandy, V.O.A.; Trilestari, K.; Sunarso, J.; Indraswati, N.; Ismadji, S. Performance of durian shell waste as high capacity biosorbent for $\mathrm{Cr}(\mathrm{VI})$ removal from synthetic wastewater. Ecological Engineering 2011, 37, 940-947, https://doi.org/10.1016/j.ecoleng.2011.01.019.

19. Singh, A.D.; Abdullah, N.; Vikineswary, S. Optimization of extraction of bulk enzymes from spent mushroom compost. Journal of Chemical Technology and Biotechnology 2003, 78, 743-752, https://doi.org/10.1002/jctb.852.

20. Kamarudzaman, A.N.; Chay, T.C.; Amir, A.; Abdul-Talib, S. Fe(II) biosorption using Pleurotus spent mushroom compost as biosorbent under batch experiment. Applied Mechanics and Materials 2014, 695, 314318, https://doi.org/10.4028/www.scientific.net/AMM.695.314.

21. Tay, C.C.; Liew; H.H.; Yong, S.K.; Surif, S.; Redzwan, G.; Abdul-Talib, S. Cu(II) removal onto fungal derived biosorbents: Biosorption performance and the half saturation constant concentration approach. International Journal of Research in Chemistry and Environment 2012, 2, 138-143.

22. Al Moharbi, S.S.; Devi, M.G.; Sangeetha, B. M.; Jahan, S. Studies on the removal of copper ions from industrial effluent by Azadirachta indica powder. Applied Water Science 2020, 10, https://doi.org/10.1007/s13201-019-1100-z.

23. Meez, E.; Rahdar, A.; Kyzas, G.Z. Sawdust for the removal of heavy metals from water: a review. Molecules 2021, 26, https://doi.org/10.3390/molecules26144318.

24. Nair, V.; Panigrahy, A.; Vinu, R. Development of novel chitosan-lignin composites for adsorption of dyes and metal ions from wastewater. Chemical Engineering Journal 2014, 254, 491-502, https://doi.org/10.1016/j.cej.2014.05.045.

25. Luo, D.; Xie, Y.; Tan, Z.; Li, X. Removal of $\mathrm{Cu} 2+$ ions from aqueous solution by the abandoned mushroom compost of Flammulina velutipes. Journal of Environmental Biology 2013, 34, 359-365.

26. Othman, N.; Asharuddin, S. Cucumis melo rind as biosorbent to remove Fe(II) and $\mathrm{Mn}$ (II) from synthetic groundwater solution. Advanced Materials Research 2013, 795, 266-271, https://doi.org/10.4028/www.scientific.net/AMR.795.266.

27. Moghadam, M.R.; Nasirizadeh, N.; Dashti, Z.; Babanezhad, E. Removal of Fe(II) from aqueous solution using pomegranate peel carbon: Equilibrium and kinetic studies. International Journal of Industrial Chemistry 2013, 4, https://doi.org/10.1186/2228-5547-4-19.

28. Zayadi, N.; Othman, N. Removal of zinc and ferum ions using Tilapia Mossambica fish scale. International Journal of Integrated Engineering 2013, 5, 23-29.

29. Phuengphai, P.; Singjanusong, T.; Kheangkhun, N.; Wattanakornsiri, A. Removal of copper(II) from aqueous solution using chemically modified fruit peels as efficient low-cost biosorbents. Water Science and Engineering 2021, https://doi.org/10.1016/j.wse.2021.08.003.

30. Zhang, Y.; Zhao, J.; Jiang, Z.; Shan, D.; Lu, Y. Biosorption of Fe(II) and Mn(II) ions from aqueous solution by rice husk ash. BioMed Research International 2014, 2014, https://doi.org/10.1155/2014/973095.

31. Abdul Rahim, A.R.; Iswarya; Johari, K.; Shehzad, N.; Saman, N.; Mat, H. Conversion of coconut waste into cost effective adsorbent for $\mathrm{Cu}(\mathrm{II})$ and $\mathrm{Ni}(\mathrm{II})$ removal from aqueous solutions. Environmental Engineering Research 2021, 26, https://doi.org/10.4491/eer.2020.250.

32. Najim, T.S.; Elais, N.J.; Dawood, A.A. Adsorption of copper and iron using low cost material as adsorbent. E-Journal of Chemistry 2009, 6, 161-168, https://doi.org/10.1155/2009/682568.

33. Sathasivam, K.; Rosemal, M.A.S.; Mas, H. Banana trunk fibers as an efficient biosorbent for the removal of $\mathrm{Cd}(\mathrm{II}), \mathrm{Cu}(\mathrm{II}), \mathrm{Fe}(\mathrm{II})$ and $\mathrm{Zn}(\mathrm{II})$ from aqueous solutions. Journal of Chilean Chemistry Society 2010, 2, 278272, http://dx.doi.org/10.4067/S0717-97072010000200030.

34. Ketsela, G.; Animen, Z.; Talema, A. Adsorption of lead (II), cobalt (II) and iron (II) from aqueous solution by activated carbon prepared from white lupine (gibito) hsuk. J Thermodyn Cataly $\mathbf{2 0 2 0}, 11$. 
35. Fathollahi, A.; Coupe, S.J.; El-Sheikh, A.H.; Nnadi, E.O. Cu(II) biosorption by living biofilms: isothermal, chemical, physical and biological evaluation. Journal of Environmental Management 2021, 282, https://doi.org/10.1016/j.jenvman.2021.111950.

36. Bashir, M.; Tyagi, S.; Annachhatre, A.P. Adsorption of copper from aqueous solution onto agricultural adsorbents: kinetics and isotherm studies. Materials Today: Proceedings 2020, 28, 1833-1840, https://doi.org/10.1016/j.matpr.2020.05.287.

37. SenthilKumar, P.; Ramalingam, S.; Sathyaselvabala, V.; Kirupha, S. D.; Sivanesan, S. Removal of copper(II) ions from aqueous solution by adsorption using cashew nut shell. Desalination 2011, 266, 63-71, https://doi.org/10.1016/j.desal.2010.08.003.

38. Khosravihaftkhany, S.; Morad, N.; Teng, T.T.; Abdullah, A.Z.; Norli, I. Biosorption of Pb(II) and Fe(III) from aqueous solutions using oil palm biomasses as adsorbents. Water, Air, and Soil Pollution 2013, 224, 114, https://doi.org/10.1007/s11270-013-1455-y.

39. Duraisamy, R.; Mechoro, M.; Seda, T.; Khan, M.A. Potential of mangifera indica activated carbon for removal of chromium and iron. Cogent Engineering 2020, 7 , https://doi.org/10.1080/23311916.2020.1813237.

40. Çelebi, H.; Gök, G.; Gök, O. Adsorption capability of brewed tea waste in waters containing toxic lead (II), cadmium (II), nickel (II), and zinc (II) heavy metal ions. Scientific Reports 2020, 10, https://doi.org/10.1038/s41598-020-74553-4.

41. Ertugay, N.; Bayhan, Y.K. The removal of copper (II) ion by using mushroom biomass (Agaricus bisporus) and kinetic modelling. Desalination 2010, 255, 137-142, https://doi.org/10.1016/j.desal.2010.01.002.

42. Zafar, S.; Khan, M.I.; Lashari, M.H.; Khraisheh, M.; Almomani, F.; Mirza, M.L.; Khalid, N. Removal of copper ions from aqueous solution using NaOH-treated rice husk. Emergent Materials 2020, 3, 857-870, https://doi.org/10.1007/s42247-020-00126-w.

43. Tavanaa, M.; Pahlavanzadeha, H.; Zareib, M.J. The novel usage of dead biomass of green algae of Schizomeris leibleinii for biosorption of copper(II) from aqueous solutions: equilibrium, kinetics and thermodynamics. Journal of Environmental Chemical Engineering 2020, 8, https://doi.org/10.1016/j.jece.2020.104272.

44. Ansari, M.I.; Masood, F.; Malik, A. Bacterial biosorption: a technique for remediation of heavy metals. In: Microbes and Microbial Technology. Ahmad, I.; Ahmad, F.; Pichtel, J. Eds.; Springer: New York, NY, 2011; pp. 283-319, https://doi.org/10.1007/978-1-4419-7931-5_12.

45. Vijayaraghavan, K.; Palanivelu, K.; Velan, M. Biosorption of copper(II) and cobalt(II) from aqueous solutions by crab shell particles. Bioresource Technology 2006, 97, 1411-1419, https://doi.org/10.1016/j.biortech.2005.07.001.

46. Han, X.; Wang, W.; Ma, X. Adsorption characteristics of methylene blue onto low cost biomass material lotus leaf. Chemical Engineering Journal 2011, 171, 1-8, https://doi.org/10.1016/j.cej.2011.02.067.

47. Tay, C.C.; Redzwan, G.; Liew, H.H.; Yong, S.K.; Surif, S.; Abdul-Talib, S. Copper (II) biosorption characteristic of pleurotus spent mushroom compost. Proceedings of International Conference on Science and Social Research, Malaysia, 2010; pp. 6-10, https://doi.org/10.1109/CSSR.2010.5773873.

48. Mzinyane, N.N.; Ofomaja, A.E.; Naidoo, E.B. Synthesis of poly (hydroxamic acid) ligand for removal of $\mathrm{Cu}$ (II) and $\mathrm{Fe}$ (II) ions in a single component aqueous solution. South African Journal of Chemical Engineering 2021, 35, 137-152, https://doi.org/10.1016/j.sajce.2020.09.002.

49. Reddya, B.J.; Palaa, S.L.; Biftua, W.K.; Suneethac, M.; Ravindhranatha, K. Effective removal of Cu(II) ions from polluted water using new bio-adsorbents. Water Practice and Technology 2021, 16, 566-581, https://doi.org/10.2166/wpt.2021.019.

50. Shukla, P.M.; Shukla, S.R. Biosorption of $\mathrm{Cu}(\mathrm{II}), \mathrm{Pb}(\mathrm{II}), \mathrm{Ni}(\mathrm{II})$, and $\mathrm{Fe}(\mathrm{II})$ on alkali treated coir fibers. Separation Science and Technology 2013, 48, 421-428, https://doi.org/10.1080/01496395.2012.691933.

51. Kariuki, Z.; Kiptoo, J.; Onyancha, D. Biosorption studies of lead and copper using rogers mushroom biomass 'Lepiota hystrix'. South African Journal Of Chemical Engineering 2017, 23, 62-70, http://dx.doi.org/10.1016/j.sajce.2017.02.001.

52. Alomá, I.; Martín-Lara, M.; Rodríguez, I.L.; Blázquez, G.; Calero, M. Removal of nickel (II) ions from aqueous solutions by biosorption on sugarcane bagasse. Journal of the Taiwan Institute of Chemical Engineers 2012, 43, 275-281, http://dx.doi.org/10.1016\%2Fj.jtice.2011.10.011.

53. Tay, C.C.; Liew, H.H.; Yin, C.Y.; Abdul-Talib, S.; Surif, S.; Suhaimi, A.A.; Yong, S.K. Biosorption of cadmium ions using Pleurotus ostreatus: growth kinetics, isotherm study and biosorption mechanism. Korean Journal of Chemical Engineering 2011, 28, 825-830, https://doi.org/10.1007/s11814-010-0435-9.

54. Nadaroglu, H.; Kalkan, E.; Demir, N. Removal of copper from aqueous solution using red mud. Desalination 2010, 251, 90-95, https://doi.org/10.1016/j.desal.2009.09.138.

55. Abood, M.M.; Rajendiran, J.; Azhari, N.N. Agricultural waste as low-cost adsorbent for the removal of Fe (II) ions from aqueous solution. Infrastructure University Kuala Lumpur Research Journal 2015, 3, 29 -39.

56. Harripersadth, C.; Musonge, P.; Isa, Y.M.; Morales, M.G.; Sayago, A. The application of eggshells and sugarcane bagasse as potential biomaterials in the removal of heavy metals from aqueous solutions. South African Journal of Chemical Engineering 2020, 34, 142-150, https://doi.org/10.1016/j.sajce.2020.08.002. 
57. Liu, X.; Chen, Z.Q.; Han, B.; Su, C.L.; Han, Q.; Chen, W.Z. Biosorption of copper ions from aqueous solution using rape straw powders: optimization, equilibrium and kinetic studies. Ecotoxicology and Environmental Safety 2018, 150, 251-259, https://doi.org/10.1016/j.ecoenv.2017.12.042.

58. Mun, N.K.; Mokhtar, N.; Shoparwe, N.F.; Shukor, H. Biosorption of copper ions from aqueous solution using kappaphycus striatum. IOP Conf. Series: Earth and Environmental Science 2021, 765, https://doi.org/10.1088/1755-1315/765/1/012033.

59. Afolabi, F.O.; Musonge, P.; Bakare, B.F. Bio-sorption of copper and lead ions in single and binary systems onto banana peels. Cogent Engineering 2021, 8, https://doi.org/10.1080/23311916.2021.1886730. 